\author{
Katarzyna Duda-Gromada \\ University of Warsaw - Faculty of Geography and Regional Studies \\ - Department of Tourism Geography and Recreation \\ 00-927 Warsaw, Krakowskie Przedmieście 30 \\ e-mail:kduda@uw.edu.pl
}

\title{
TOURISM MANAGEMENT IN THE VICINITY OF THE SELECTED RETENTION RESERVOIRS IN POLAND
}

\begin{abstract}
The creation of a retention reservoir causes changes in the management of its vicinity. Tourism functions develop, and as a result the tourism infrastructure also develops. In the paper, selected aspects of the tourism management in the vicinity of two retention reservoirs in Poland (Solina and Tresna) are discussed. The author characterizes the accommodation, catering, transport, and supplementary infrastructures. Also, the results of an opinion poll rating these elements of the infrastructure are presented.
\end{abstract}

Key words: tourism management, retention reservoirs, the Solina reservoir, the Tresna reservoir

One of the results of the creation of a retention reservoir are the changes in land management. Spatial systems in the immediate environment change, migrations of population occur, agricultural production changes and becomes limited, and the tourist function appears. Jackowski (1984) calls such an impact of reservoirs indirect (secondary) impact. Appropriate management of such an area can be a source of success in the development of the commune. For that reason (see Zwoliński 1992), to prevent a chaotic management, a planning assessment of the vicinity of a reservoir should be performed for all reservoirs, even for ones that are still in the planning stages. A lively development activity is caused by two factors. One of them is the construction of new houses by the inhabitants of the flooded villages (the 
resettlement effect), the other one - the creation of a tourism base in a wide sense of this word.

Tourism infrastructure comprises facilities which have been classified by Rogalewski (1974). He divided them into tourism and paratourism facilities. The former include facilities whose basic purpose is tourism service, while the purpose of the latter is to satisfy the needs related to other aspects of life, with tourists being only one of many groups using them. According to Różycki (2006), however, tourism infrastructure is divided into:

- transport infrastructure,

- accommodation infrastructure,

- catering infrastructure,

- accompanying (supplementary) infrastructure.

Similarly, Rogalewski (1974), quoted earlier, divided the so-called material base of tourism and gave it a particular importance in tourism management. For that reason, the above scheme has been accepted in this paper, in the discussion of land management in the vicinity of retention reservoirs.

Two reservoirs have been chosen: Solina and Tresna (the latter commonly known as Lake Żywieckie), created in the 1960s. Their main objectives, according to the Technical Centre of Dam Control, are: flood prevention, electrical energy production, recreation, and in the case of Tresna, also water supply. The surface area of the reservoirs are: Solina $21 \mathrm{~km}^{2}$, Tresna $10 \mathrm{~km}^{2}$.

The statistical data presented here refer to administrative units, that is to communes (gmina) with good access to the reservoir. These are: in the case of Solina - the communes of Solina and Czarna; in the case of Tresna - the communes of Żywiec and Łodygowice. In regard to the length of the accessible coast, the privileged ones among them are the communes of Solina and Żywiec.

Next to the characteristics of the tourism infrastructure, an interesting issue is the opinion about this infrastructure by persons using it, that is, by tourists. In July 2006 the author conducted an opinion poll among the tourists in the vicinity of the reservoirs. At the Solina reservoir, 205 questionnaires were filled out and near Tresna, 200. The respondents were asked, among other things, to rate the individual elements of the tourism infrastructure by giving points on the scale from 1 to 5 (with 1 being the worst evaluation and 5 the best). The respondents could also mark 0 , meaning no opinion on the element in question. 


\section{ACCOMMODATION FACILITIES}

According to the World Tourism Organization, an accommodation facility is an establishment offering overnight accommodation in a room or another space to a traveller; the number of places offered must be greater than a minimum (defined by individual countries) and all the places in the establishment must be uniformly managed on commercial basis (Kowalczyk 2001). In Poland, accommodation infrastructure includes, in accordance with the Act on tourism services of 1997, establishments such as:

- hotels,

- motels,

- guesthouses,

- excursion houses,

- camping sites,

- tent sites,

- youth hostels,

- hostels.

Also, recreational centres, retreat houses, pilgrim houses, luxury suites, agrotourism farms and private quarters are accommodation establishments (Różycki 2006).

The size of the accommodation base in the communes under discussion is shown in Table 1.

Table 1.

Accommodation facilities in individual communes in 2004

\begin{tabular}{|c|c|c|c|c|c|}
\hline \multirow{2}{*}{ Reservoir } & Commune & $\begin{array}{c}\text { Number of accom- } \\
\text { modation estab- } \\
\text { lishments in July }\end{array}$ & $\begin{array}{c}\text { including all } \\
\text { year-round }\end{array}$ & $\begin{array}{c}\text { Number of } \\
\text { bed-places } \\
\text { in July }\end{array}$ & $\begin{array}{c}\text { including all } \\
\text { year-round }\end{array}$ \\
\hline \multirow{2}{*}{ Solina } & Solina & 17 & 11 & 2096 & 1787 \\
\cline { 2 - 6 } & Czarna & 3 & 0 & 105 & 0 \\
\hline \multirow{2}{*}{ Tresna } & Żywiec & 7 & 5 & 467 & 387 \\
\cline { 2 - 6 } & Łodygowice & 5 & 2 & 245 & 178 \\
\hline
\end{tabular}

Source: based on Bank of Regional Data 2004

The accommodation facilities at the Solina reservoir are located mostly in the commune of Solina. The commune of Czarna has fewer bed spaces, which results from its more limited access to the reservoir. Tourism infrastructure is very differentiated here. There are hotels, guesthouses, resorts, sanatoriums, camping sites and so on. There 
are also private quarters and agrotourist farms. In the commune of Solina there were 100 registered agrotourist farms and 90 farms offering private rooms (Sroczyński 2006). Accommodation for tourists can be found in almost every locality.

In the vicinity of the Tresna reservoir the accommodation base is less developed, both in regard to the number and the standard of establishments. There are very few agrotourist farms, since the commune of Żywiec is an urban commune. Characteristic features of this area are dilapidated resorts which used to be owned by large industrial plants from Upper Silesia and now, despite of advantageous location (next to the reservoir), are not in service.

The accommodation facilities at the Solina reservoir was rated higher by the respondents than the one at the Tresna reservoir (Fig. 1).

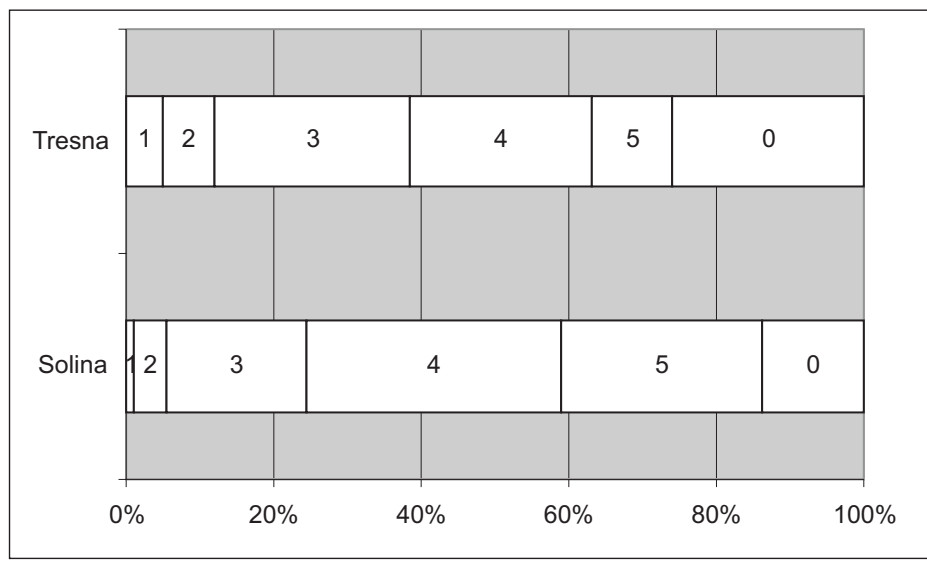

1 - lowest rating, 5 - highest rating, 0 - no opinion

Fig. 1. Rating of accommodation infrastructure

Source: Author's materials

The Solina facilities were rated as good and very good by $62 \%$ of the respondents, while those at Tresna by only $36 \%$. The large percentage of respondents who had no opinion about the Tresna facilities (26\%) is caused by the specific character of tourism there: a large part of those polled are one-day visitors who do not use overnight accommodation facilities. 
Most of those polled at Solina use accommodation facilities in private homes and in agricultural farms (almost 90 people), while at Tresna, the main accommodation used are camping sites and bungalows.

\section{FOOD FACILITIES}

Food facilities can be divided into three groups:

- catering establishments,

- trade establishments supplying food products to tourists - food stores,

- establishments providing adequate supplies to catering establishments and stores.

In the commune of Solina there are 65 registered trade entities and 11 registered catering entities, while in the commune of Czarna, there are 26 and 18, respectively (Plans of local development of the Solina and Czarna communes). The vast majority of these services, especially of catering ones, are geared to tourist service and is open only in season (in the summer).

In the commune of Łodygowice there are 487 registered trade entities and 43 registered catering entities (Plan of the development of the commune of Łodygowice).

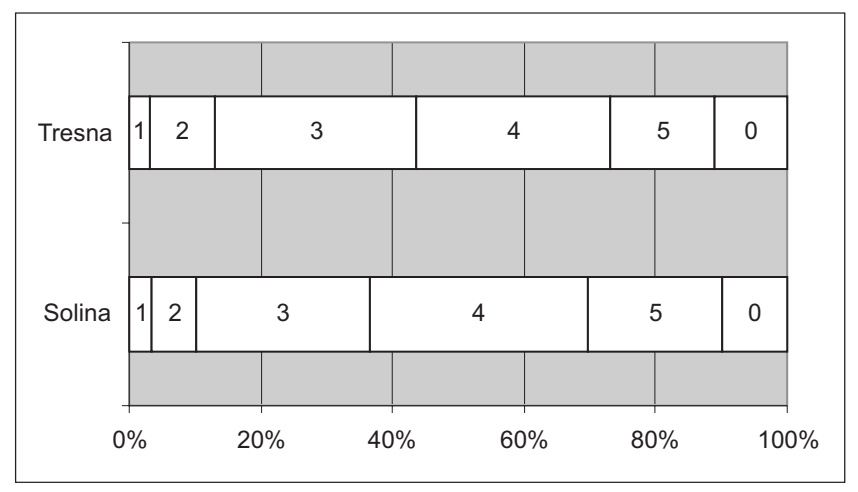

1 - lowest rating, 5 - highest rating, 0 - no opinion

Fig. 2. Rating of catering infrastructure

Source: Author's materials 
Tourists rate the food facilities near the Solina and Tresna reservoirs similarly, with slightly more positive ratings at Solina (Fig. 2). At Solina, 33\% of the respondents rate these facilities as good, and at Tresna, such rating is given by $29 \%$ of the respondents. Very good ratings are given by $20 \%$ and $16 \%$ of the respondents, respectively.

\section{TRANSPORT FACILITIES}

A classification of transport infrastructure is presented by Różycki (2006). He distinguishes:

- transport routes - roads, highways, railway lines, as well as ferry lines and air lines;

- means of transport - cars, coaches, trains, ferries, airplanes;

- tourist service units - service stations, gas stations, railway stations, air terminals;

- technical-service base and organization of transport services.

For tourists, it is the transport network that is important, its density and quality, traffic capacity, spaciousness, and, even, the cleanliness and competence of employees.

The road network on the vicinity of the Solina reservoir has been created in the 1960s, when two by-pass roads were built: a large one and a small one. Two segments of voivodship roads (no. 894 and 895) run through the commune of Solina. There is no railway transport. Because of large uninhabited areas in the commune of Czarna, the road network there is fairly adequate.

Żywiec is connected by means of a national and regional road network with the most important regional centres: with Bielsko-Biała, by the national road no. 94 or the regional road no. 942; with Katowice, by the national road no. 94 and then by the national road no. 1; with Kraków, via Bielsko-Biała, then by the national road no. 96 or by the regional roads no. 946 and 947 and by the national road no. 96, or else via the towns of Sucha Beskidzka, Wadowice, and the national road no. 96. The standard of roads is low, mostly due to inadequate road parameters and to the traffic load exceeding their capacity. The town of Żywiec is also connected with the above mentioned centres by passenger railway. Two railway lines run through the town; they are accessible from two stations: Żywiec and Żywiec Sporysz. Unfortunately, due mostly to the small number of trains, railway is not of 
large importance. Research confirms this: only 9 of those polled at the Tresna reservoir named the train as the means of transport. Next to national and regional roads, district roads and town streets are of some importance. There is both private and municipal bus transport. The former is of particular importance for local and inter-commune connections. The municipal transport services transport people both within towns and between neighbouring localities.

In the commune of Łodygowice there are: the national road no. 69, district roads and communal roads. $112 \mathrm{~km}$ of communal roads have a tarmac surface, the remaining ones are paved.

Research shows that most of those polled use cars as a means of transport (Solina 81\%, Tresna 94\%). Coach and train were named by the respondents at Solina.

Transport accessibility was rated very similarly by the respondents at Solina and Tresna (Fig. 3). Slightly over 50\% of those polled rated it 3 or 4 . The percentage of the respondents who had no opinion on transport services is relatively high: $22 \%$ at Solina, $16 \%$ at Tresna.

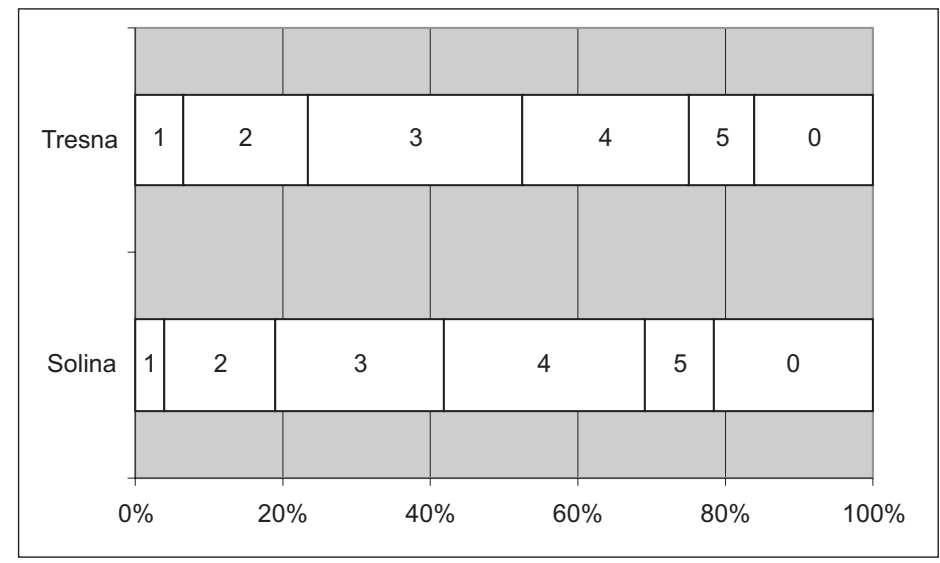

1 - lowest rating, 5 - highest rating, 0 - no opinion

Fig. 3. Rating of transport accessibility

Source: Author's materials

The respondents rated the opportunities to park one's car as better in Solina than in Tresna. Over 30\% of the respondents in Tresna rated it 1 or 2 , and in Solina as many as $41 \%$ rated it 4 or 5 . 


\section{SUPPLEMENTARY FACILITIES}

The supplementary infrastructure contains elements supplementing the tourist offer. Rogalewski (1974) distinguishes:

- facilities that enable tourists to take advantage of tourist amenities;

- tourist agencies, travel agencies;

- entertainment establishments;

- service establishments.

Objects or services used by tourists belong not only to the tourism infrastructure, but also to the para-tourism infrastructure.

In the commune of Solina there are many boat rentals; in the summer season, at least 10-15 are in service, and in the high season additional establishments are open at bathing resort and tent sites (Sroczynski 2006). Also, short cruises are offered on the reservoir. There are also some bicycle routes of various length (from $4 \mathrm{~km}$ to $54 \mathrm{~km}$ ), including the Cultural Bicycle Trail „Along the San River Fortifications" whose length in the commune is $10,5 \mathrm{~km}$. For those who have no bicycle of their own there are rentals of mountain bicycles. In the commune there are also walking trails of duration from ca. $30 \mathrm{~min}$. to 5 hours. Recently it has been also possible to visit the water power plant. Moreover, the are horse stud farms, fish ponds, an ostrich farm, and a ski lift in the commune.

The bicycle trail „The Green Bicycle” $(60 \mathrm{~km})$ runs through the commune of Czarna; it is part of the international bicycle trail „Greenway - Eastern Carpathians". There are also hiking trails; moreover, two T-bar lifts are located in the commune. Trips by snowmobile are offered, as well as sleigh rides.

Two lowland hiking trails run through the town of Żywiec and its environs (The Liberation of Żywiec Hiking Trail and the Swedish Invasion Trail), and three mountain trails lead from the town. In the town itself there are swimming pools (one covered), sports hall, tennis court, and a bowling alley. Two T-bar lifts are also in service.

In the commune of Łodygowice there are tourist trails through the Beskidy Mountains surrounding the commune.

As we can see, the commune of Solina is distinguished from all the units under analysis in regard to its tourism infrastructure. Of all the communes under discussion, it is the one with the best tourism management. It is characterized by a variety of accommodation 
facilities, or available services. The commune of Żywiec, as the only town commune (among those under discussion), has a rich bus transport system belonging to the para-tourism infrastructure, since the system is used above all by the entire population. The communes of Czarna and Łodygowice, due to their limited access to the reservoir, have a more modest infrastructure. Tourism in the vicinity of each reservoir is of seasonal character, as a result of which most tourist services are in operation during the season only.

Tourists rated the tourism infrastructure at Solina higher than that at Tresna. The largest divergence of opinion occurs in the case of accommodation facilities. The catering facilities and transport accessibility were rated similarly at both places with a slightly larger number of better ratings at the Solina reservoir. Such a rating of the infrastructure by tourists shows the number and quality of the services, which depend on several aspects.

The commune of Żywiec, within which the largest part of the Tresna reservoir is located, is a town commune. For that reason one can observe that the local authorities care less about the tourism management of the reservoir than do the other communes, such as for instance Łodygowice. Also, the local population does not show much initiative in development of tourist services through offers of overnight stays. The authorities of other, non-town communes, care particularly about tourism management, since they see opportunities of social-economic development in tourism.

In the commune of Solina, the only industrial plant is the hydropower plant Solina-Myczkowce. Because of that, the development of this commune depends on other branches of economy. Solina's attractive location and the presence of the reservoir combine to create a significant attractiveness of the area. Therefore, the development of the commune can be based on tourism. This is noticed by both the local authorities and by the inhabitants. Various activities aiming at the development of tourism in the area, development and modernization of tourism infrastructure are among the priority objectives. The local population is active in offering numerous tourism and para-tourism services. For that reason, the tourism infrastructure is well developed here. What is characteristic here is the variety of the accommodation base, both in regard to the size of the facilities and the standard of services offered.

The tourism infrastructure at the Tresna reservoir was to a large extent dependent on the industrial plants of the Upper Silesian In- 
dustrial District. The vicinity of the reservoir was a holiday base for this region. Several resorts were created; currently they are not used because of inadequate funding for the region. At the Solina reservoir, however, the infrastructure is relatively new, and geared to the needs of the modern tourist.

\section{REFERENCES}

Bartnik M., Bogaczyk A., 2005, W gminie Czarna [In the Municipality of Czarna; in Polish], ROKSANA, Krosno.

Jackowski A., 1984, Wpływ zbiorników retencyjnych na strukturę społeczno-gospodarcza ich otoczenia [The Impact of Retention Reservoirs on the Social-Economic Structure of their Environment; in Polish], Czasopismo Geograficzne, LV, 3.

Kowalczyk A., 2001, Geografia turyzmu [Geography of Tourism; in Polish], Wydawnictwo Naukowe PWN, Warszawa.

Łukacz I. et al., 2007, Gmina Solina [The Municipality of Solina; in Polish], ROKSANA, Krosno.

Plan rozwoju gminy Eodygowice na lata 2005-2009 [Plan of the Development of the Municipality of Łodygowice for 2005-2009; in Polish].

Plan rozwoju lokalnego gminy Czarna [Plan of the Development of the Municipality of Czarna; in Polish], Bieszczadzka Agencja Rozwoju Regionalnego, 2004.

Plan rozwoju lokalnego gminy Solina na lata 2004-2013 [Plan of the Development of the Municipality of Solina for 2005-2009; in Polish], RES Management S.C., 2004.

Rogalewski O., 1974, Zagospodarowanie turystyczne [Tourism Management; in Polish], Wydawnictwa Szkolne i Pedagogiczne, Warszawa.

Różycki P., 2006, Zarys wiedzy o turystyce [Outline of Tourism; in Polish], PROKSENIA, Kraków.

Sroczyński W. (ed.), 2006, Studium form i mechanizmów degradacji środowiska $w$ systemach rekreacyjnych brzegów jezior zaporowych południowo-wschodniej Polski, Wydawnictwo IGSMiE PAN, Kraków.

Studium uwarunkowań $i$ kierunków zagospodarowania przestrzennego miasta Żywca, część I-uwarunkowania, studia i analizy [Study of the Conditions and Directions of Spatial Management of the Town of Zywiec, Part I - Conditions, Studies, and Analyses; in Polish], P.A. NOVA SP. Z O.O., Gliwice.

Zwoliński A., 1992, Ocena walorów turystyczno-rekreacyjnych sztucznych zbiorników (na przykładzie zbiorników nizinnych) [An Estimate of Tourism and Recreation Amenities of Artificial Reservoirs (on the Example of Lowland Reservoirs; in Polish], Instytut Turystyki, Warszawa.

English translation: Matgorzata Mikulska 